\title{
Surgical Resection of Myxoma with Treated Pulmonary Hypertension: Case Report
}

\author{
Mehmet Atay', Onur Saydam², Vedat Bakuy ${ }^{3}$
}

\footnotetext{
1) Bakırköy Training and Research Hospital Cardiovascular Surgery Department, İstanbul, Turkey

${ }^{2)}$ Karaman State Hospital Cardiovascular Surgery Department, Karaman, Turkey

${ }^{3)}$ Bakırköy Training and Research Hospital Cardiovascular Surgery Department, İstanbul, Turkey
}

\section{Introduction}

Pulmonary arterial hypertension (PAH), can be defined as mean pulmonary artery pressure (PAP) is higher than $25 \mathrm{mmHg}$ during resting wheras higher than $30 \mathrm{mmHg}$ during exercising. Although it progresses asymptomatically for years, most frequently comes out as exertional dyspnea. ${ }^{(1)}$ Since prognosis changes depending on the reason beneath, its mortality is high if it is not treated. Right ventricule dilatation and right ventricule failure is inevitable in untreated facts. As there are various classification methods, in 2008 at last DANA Classification was developed by protecting general philosophical approaches and structure. (Table 1) ${ }^{(2)}$ As it is seen in this classification pulmonary arterial hypertension (PAH) confronts us rarely depending on left atrial myxoma. In this article in a fact applied with respiratory disorder, giant left atrial myxoma causing pulmonary hypertension was obtained in echocardiographic examination (EKO). A fact that the complaints recovered after myxoma surgical treatment was presented.

\section{Case}

40 year old female patient was admitted to department of chest diseases intermittently with dyspnea for 3 months. She was applied to bronchodilator therapy (Picture 1). After treatment there was not any regression in complaints of patient. The patient does not have any known disease. The patients was sent to our clinic for advance inspection and treatment. In her echocardiagraphic examination left ventriculous fraction (LVEF) was $50 \%$, systolic PAB was measured as $80 \mathrm{mmHg}$ and a bulk in left atrium with $77 \times 29 \mathrm{~mm}$ size, moving, compatible with myxoma was obtained (Picture 2). Coronary angiography was performed and reported normal. 
The patient was decided to have surgical resection of myxoma via right atriotomy under cardiopulmonary by-pass (Picture 3). The pathological examination of bulk was reported as myxoma morphology involving calcification centres. After intensive care and clinical follow ups the patient was discharged from hospital with healing. In echocardiography done after 2 months from operation, no bulk recurrence was obtained. The complaints of respiratory disorders regressed. As LVEF: 50\% and sPAB:33 mmHg was reported. In the result of EKO done in 2nd year control of patient that continued routine polyclinical follow ups, as $\mathrm{sPAB}<35 \mathrm{mmHg}$, LVEF: 50\% was reported.

\section{Discussion}

PAH is a slowly progressing disease that is diagnosed late and it is most frequently seen in 3rd-4th decade of women. ${ }^{(1)}$ PAH patients are defined as primary since there was no other disease beneath. In secondary PAH left heart failure, chronic lung diseases, hypoxemia reasons, infections, rheumatic diseases can be counted. In a study done with 187 patients the most frequently seen symptom was reported as exertional dyspnea. Fatigue, chest pain, syncope, leg oedema and tachycardia were reported as other symptoms. ${ }^{(1,3)}$ Various classifications were done by updating datas regarding disease. Some regulations were done by protecting structure and general philosophic approach in Evian-Venice classification modified in 2004 with taking new datas in Dana Point, California in 2008 into consideration.

In this classification that is called as DANA Classification PHT obtained clinical situations were seperated into five groups according to pathological, physiopathological and therapeutic properties. Although there are same level of increses in PAP values of different clinical groups and pulmonary vascular resistence values, mechanisms, diagnostic approaches beneath them and their prognostic and therapeutic results are completely different from eachother. ${ }^{(2)} \mathrm{PAH}$ in the second group of DANA classification that is connected with left heart diseases, is seen in frequently protected and low LVEF cardiac insufficiency patients. ${ }^{(4)}$

The patients in this group are formed of generally old, female gender, having systemic hypertension histo- ry and metabolic syndrome properties in most of them. $(5,6)$ Some of the rare conditions within this group are left atrial myxoma or conditions following pulmonary venous flow resistance increase that develop depending on cor triatrum. ${ }^{(7)}$

Myxoma that is rarely seen, comes out in our fact as the reason of pulmonary hypertension. Myxomas are most frequently seen in left atrium (75\%) can also be seen in right atrium (15-20\%), right ventricule $(6 \%)$ and rarely in left ventricule. They do not generally show symptoms. ${ }^{(8)}$ Symptoms cause systemic embolies in cardiac cavities they place in by making obstruction or deformation on valves. In the study that Yildirım et. al published, left atrial myxoma in EKO of 2 facts having respiratory disorder, was obtained. Respiratory disorder complaint of patient got better after a successful surgery. ${ }^{(9)}$ Zaher et. al presented a patient having stomachache and respiratory disorder which they found myxoma accidentally in tomography.

They reported that the symptoms of patient got better after a successful surgery. ${ }^{(10)}$ Again Schauer et. al. found myxoma as an etiologic reason in a patient having dyspnea and hemoptysis. The patient was treated with a successful surgery. ${ }^{(1)}$ Also in our case the symptoms of patient disappeared dramatically after surgical resection. In transthoracic echocardiography done for follow ups, it was seen that PAH got better. In addition to the inspections, transthoracical echocardiography done to the patient that his symptoms came out in the last two years. In detection of PAP, echocardiography the sensitivity was in $0,79-1$, specifity was in $0,69-0,98$ interval. ${ }^{(1)}$ Since it is an easy used method after a detailed physical examination, it comes out as a beneficial method in patients having respiratory disorder. Also the complaint of our petient was respiratory disorder.

In addition to inspections the patient was evaluated with echocardiography and systolic PAP was obtained as $80 \mathrm{mmHg}$. A severe PAH was observed in patient. In addition to this, when the reasons beneath were examined any reason could not obtained except left atrial myxoma. After surgical myxoma resection, in his follow ups it was seen that exertional dyspnea regressed. Systolic PAP values of patient were observed normal in echocardiographies done after 6 months and 2 year. 
As it is seen from the fact that left atrial myxoma that is mentioned in the second group of DANA classification can come out rarely as being the reason of PAH. The treatment of cardiac myxomas are surgical with very successful results. ${ }^{(7,10,11)}$ We believe that taking the result of echocardiography which is a simple technique, into consideration will be life saving in order not to miss out the reasons beneath respirotary disordered patients.

\section{Declaration of Conflict of Interests}

The authors declared that there is not any conflict of interests in preparing and publication of this article.

\section{Financing}

The authors declared that they did not get any financial support during searching and writing period.

\begin{tabular}{|c|c|c|}
\hline Group 1 & Pulmonary Arterial Hypertension & $\begin{array}{l}\text { Idiopathic, Genetic, Depending on } \\
\text { medicine and toxins or other diseases } \\
\text { (Collagenosis, HIV, Portal Hypertension, } \\
\text { Chronicle Hemolytic Anemia, } \\
\text { Congenital Heart Disease) }\end{array}$ \\
\hline Group 2 & Depending on Left Heart Disease & $\begin{array}{l}\text { Systolic disfunction, Diasytolic } \\
\text { disfunction, valvular disease }\end{array}$ \\
\hline Group 3 & $\begin{array}{c}\text { Pulmonary hypertension } \\
\text { depending on lung diseases } \\
\text { and / or hypoxy }\end{array}$ & $\begin{array}{l}\text { COLD, Interstitial lung disease, } \\
\text { Respiratory disorders during sleep, } \\
\text { luns diseases such as Alveolar } \\
\text { hypoventilation disorders }\end{array}$ \\
\hline Group 4 & $\begin{array}{c}\text { Chronical thromboembolic } \\
\text { pulmonary hypertension }\end{array}$ & \\
\hline Group 5 & $\begin{array}{c}\text { PH with aspecific mechanisms } \\
\text { and / or multi factored }\end{array}$ & $\begin{array}{l}\text { a. Hematological disorders } \\
\text { b. Systemic disorders } \\
\text { c. Metabolic disorders } \\
\text { d. Others (tumoural obstruction, fibrous } \\
\text { mediastinitis, depending on dialysis CRI) }\end{array}$ \\
\hline
\end{tabular}




\section{References}

1. Öztürk Ö, Şahin Ü, Pulmoner arteriyel hipertansiyon: tanı ve tedavisi, Süleyman Demirel Üniversitesi Tıp Fakültesi Dergisi 2009:16(1): 39-47

2. Simonneau G, Robbins I, Beghetti M, Channick RN, Delcroix M, Denton $\mathrm{CP}$ et all.Updated clinical classification of pulmonary hypertension. J Am Coll Cardiol 2009;54:43 -54

3. Barst RJ, McGoon M, Torbicki A, Sitbon O, Krowka MJ, Olschewski H et al. Diagnosis and differential assessment of pulmonary arterial hypertension. J Am Coll Cardiol 2004;43(12):40-7

4. Fang JC, DeMarco T, Givertz MM et al. World Health Organization Pulmonary Hypertension Group 2: Pulmonary hypertension due to left heart disease in the adult summary statement from the Pulmonary Hypertension Council of the International Society forHeart and Lung Transplantation. J Heart Lung Transplant 2012;31:913-33

5. Thenappan T, Shah SJ, Gomberg-Maitland M et al. Clinical characteristics of pulmonary hypertension in patients with heart failure and preserved ejection fraction. Circ Heart Fail 2011;4:257-65.
6. Robbins IM, Newman JH, Johnson RF et al. Association of the metabolic syndrome with pulmonary venous hypertension. Chest 2009;136:31-6

7. Erer B, Eren M, Sol kalp hastalığına bağlı pulmoner hipertansiyon, Anadolu Kardiyol Derg 2010; 10: Özel Sayı 2; 42-6

8. Keçeligil HT, Demir Z, Kolbakır F, Demirağ MK, AKAR H, Kardiyak Miksoma ve Cerrahi Tedavisi, Turk Gogus Kalp Dama Mayıs 1999, Cilt 7, Sayı 3, Sayfa(lar) 210-216

9. Yıldırım E, İkitimur B, Döventaş A, Cengiz M, Erdinçler DS, Beğer $\mathrm{T}$, Nefes darlığının nadir bir nedeni olan iki miksoma olgusu, Turkish Journal of Geriatrics 2012; 15 (1) 106-110

10. Zaher MF, Bajaj S, Habib M, Doss E, Habib M, Bikkina M et all, A Giant Left Atrial Myxoma, Hindawi Publishing Corporation Case Reports in Medicine Volume 2014

11. Schauer SG, Eisenman JC, A Woman with Dyspnea and Hemoptysis, Western Journal Of Emergency Medicine Volume XV, NO. 7 : November 2014

Received: 11/02/2016

Accepted: 08/03/2016

Published: 15/03/2016

Disclosure and conflicts of interest:

Conflicts of interest were not reported.

\section{Corresponding author:}

Dr. Mehmet Atay

Mail: drataym@gmail.com 